\title{
Body fat and cholecalciferol supplementation in elderly homebound individuals
}

M.H.S. Canto-Costa, I. Kunii and O.M. Hauache
Disciplina de Endocrinologia, Escola Paulista de Medicina, Universidade Federal de São Paulo, São Paulo, SP, Brasil

\author{
Correspondence \\ O.M. Hauache \\ Laboratório de Endocrinologia \\ Molecular \\ Disciplina de Endocrinologia \\ EPM, UNIFESP \\ Rua Pedro de Toledo, 781, 12ㅇandar \\ 04039-032 São Paulo, SP \\ Brasil \\ E-mail: omar.hauache@fleury.com.br
}

Research supported by FAPESP (No. 02/11782-5).

Received November 19, 2004 Accepted August 5, 2005

\begin{abstract}
Vitamin D deficiency, observed mainly in the geriatric population, is responsible for loss of bone mass and increased risk of bone fractures. Currently, recommended doses of cholecalciferol are advised, but since there are few studies evaluating the factors that influence the serum levels of 25-hydroxyvitamin D (25(OH)D) following supplementation, we analyzed the relationship between the increase in serum $25(\mathrm{OH}) \mathrm{D}$ after supplementation and body fat. We studied a group of 42 homebound elderly subjects over 65 years old ( 31 women) in order to assess whether there is a need for adjustment of the doses of cholecalciferol administered to this group according to their adipose mass. Baseline measurements of $25(\mathrm{OH}) \mathrm{D}$, intact parathyroid hormone and bone remodeling markers (osteocalcin and carboxy-terminal fraction of type 1 collagen) were performed. Percent body fat was measured by dual-energy X-ray absorptiometry. The patients were divided into three groups according to their percent body fat index and were treated with cholecalciferol, 7,000 IU a week, for 12 weeks. The increases in serum levels of 25(OH)D were similar for all groups, averaging $7.46 \mathrm{ng} / \mathrm{mL}(\mathrm{P}<0.05)$. It is noteworthy that this increase only shifted these patients from the insufficiency category to hypovitaminosis. Peak levels of 25(OH)D were attained after only 6 weeks of treatment. This study demonstrated that adipose tissue mass does not influence the elevation of $25(\mathrm{OH}) \mathrm{D}$ levels following vitamin $\mathrm{D}$ supplementation, suggesting that there is no need to adjust vitamin $\mathrm{D}$ dose according to body fat in elderly homebound individuals.
\end{abstract}

Key words

- Cholecalciferol

- Vitamin D insufficiency

- Secondary

hyperparathyroidism

- Obesity

- Body fat content

\section{Introduction}

Vitamin D insufficiency has been diagnosed mainly in the elderly and is responsible for the loss of bone mass, leading to an increased risk of bone fractures. Low levels of vitamin D are related to secondary hyperparathyroidism and elevation in the levels of bone remodeling markers (1-4). Several factors are considered determinants of baseline serum levels of 25-hydroxyvitamin D (25(OH)D). These include age, race and season of the year; other factors such as obesity, however, have been studied only recently (5-7).

Some specific characteristics of vitamin 
D physiology have been associated with obese people. Serum parathormone (PTH) and 1,25-dihydroxyvitamin $\mathrm{D}\left(1,25(\mathrm{OH})_{2} \mathrm{D}\right)$ levels are elevated in obese men and women but serum 25(OH)D levels are lower when compared to non-obese individuals $(6,7)$. Elevation of urinary cyclic AMP levels and a decrease of serum calcium levels have also been described in these patients when compared to non-obese people matched for age (8). Although the explanation for the increase in the risk of vitamin $\mathrm{D}$ deficiency in the obese individuals is unknown, it has been postulated that this population, due to lower mobility, is less exposed to sun radiation which is crucial for skin synthesis of vitamin $\mathrm{D}$ (9). It is also assumed that an increase in production of the active form of vitamin $\mathrm{D}\left(1,25(\mathrm{OH})_{2} \mathrm{D}\right)$ plays a role in the negative feedback over liver hydroxylation, limiting the synthesis of $25(\mathrm{OH}) \mathrm{D}(6)$.

In the 1970's, some studies were published reporting a correlation between vitamin D and fat tissue: Mawer et al. (10) demonstrated that parenterally administered radiolabeled vitamin D was found in high concentrations in adipose tissue. Liel et al. (7), when evaluating people with morbid obesity, suggested that the decrease of serum $25(\mathrm{OH}) \mathrm{D}$ in this population could be secondary to a change in the distribution of vitamin $\mathrm{D}$ associated with increased vitamin D storage in adipose tissue. Worstman et al. (11) compared the elevation of serum levels of $25(\mathrm{OH}) \mathrm{D}$ in obese and non-obese individuals after exposure to UVB radiation and after orally administered ergocalciferol, confirming the reduction in vitamin D bioavailability in obese individuals. On the basis of this evidence, obese people would be expected to need higher doses of supplementary vitamin $\mathrm{D}$ than thin people.

In the last few years, with the advances in the study of osteoporosis in elderly people, a strong correlation between low bone mass and vitamin D insufficiency was found in the elderly (12). These observations changed the way how one determines the ideal levels of vitamin D. In this regard, deficiency was formerly accepted as levels associated with osteomalacia. Currently, the trend toward elevation of PTH levels is accepted to characterize hypovitaminosis $\mathrm{D}$, being related to elevation of risk of bone fractures $(13,14)$. It is important to know which factors influence the serum levels of vitamin D and which factors modify these levels after vitamin D supplementation, so that inadequate treatment can be avoided. Adiposity seems to play a role in the decrease of vitamin $D$ levels; however, it remains unclear whether it interferes with elevation of these levels after vitamin $\mathrm{D}$ replacement.

We studied 42 geriatric patients living in a nursing home in São Paulo, SP, Brazil. They received oral vitamin D (cholecalciferol) on a weekly basis for 3 months. Serum vitamin D levels and their correlation with adipose tissue parameters were evaluated.

\section{Subjects and Methods}

All subjects were over 65 years old and had been living in a nursing home in São Paulo, SP, Brazil, for at least 6 months. After initial selection, we excluded patients with renal problems (serum creatinine $>1.4 \mathrm{mg} /$ $\mathrm{dL}$ ), elevation of liver enzymes (ALT and AST), primary hyperparathyroidism, other causes of hypercalcemia, hypercalciuria, endstage diseases, Paget disease, past history of nephrolithiasis, bedridden patients, and patients using medications known to interfere with bone metabolism such as corticosteroids, bisphosphonates, anticonvulsants, lithium, thiazide diuretics, sodium fluoride, vitamin D and/or calcium. On this basis, of 55 patients initially selected, 31 women and 11 men participated in and concluded the study. The study was approved by the Ethics Committee of the Federal University of São Paulo and all subjects signed an informed consent form. All patients were able to walk and carry out their daily living activities and 
were capable of understanding the objectives of the study. Daily calcium intake, based on reported weekly food intake, averaged less than $500 \mathrm{mg}$ a day.

Total calcium (reference values (RV): 8.4-10.2 $\mathrm{mg} / \mathrm{dL}$ ), ionic calcium (RV: 1.15 and $1.40 \mathrm{mmol} / \mathrm{L}$ ), magnesium (RV: 1.9-2.5 $\mathrm{mg} / \mathrm{dL}$ ), albumin (RV: $3.5-5.0 \mathrm{~g} / \mathrm{dL}$ ), and creatinine (RV: $0.8-1.2 \mathrm{mg} / \mathrm{dL}$ ) were measured and analyzed using standard protocol of the laboratory (UNIFESP). An electrochemiluminescence immunoassay (Elecsys analyzer, Roche, Mannheim, Germany) was used to measure PTH (RV: $15-65 \mathrm{pg} / \mathrm{mL}$ ), carboxyl-terminal fraction of type 1 collagen (CTX-s; RV: 0.010-5.94 ng/mL) and osteocalcin (OC; RV: 11-43 ng/mL). Levels of 25(OH)D were measured by HPLC using a Chromsystem kit (Munchen, Germany), ranging from 10 to $60 \mathrm{ng} / \mathrm{mL}$ (mean total coefficients of variation were $10 \%$ ). Blood samples reserved for the measurement of PTH were stored in cooled tubes and conserved in ice. All samples were centrifuged for about $1 \mathrm{~h}$ after collection. Serum samples were distributed into vials and kept in a freezer until the measurements, except for ionic calcium determination, which was carried out immediately.

Vitamin D (cholecalciferol) drops (Magister Handling Pharmacy Ltd., São Paulo, SP, Brazil), 1,000 IU/drop, were administered. The content of vitamin $\mathrm{D}$ found in this medication was analyzed by Tishcon Corp. (Westbury, NY, USA) revealing 1,100 IU/ drop. The medication was handled all at once and conserved at a temperature of $8^{\circ} \mathrm{C}$ protected from light.

Each participant was submitted to a total body scan using dual-energy X-ray absorptiometry with a radiation densitometer (HOLOGIC, model 4500 A, Waltham, MA, USA). The coefficient of variation for total body fat measurements was $1.26 \%$.

\section{Study design}

This was a prospective 3-month study.
The untreated group was composed of 11 patients chosen for their lower but still normal levels of PTH because they would not receive any sort of treatment, and our main objective regarding this group was to confirm the stability of $25(\mathrm{OH}) \mathrm{D}$ levels during the study. The remaining patients received cholecalciferol, 7,000 IU a week for 12 weeks, personally provided by one of the authors who counted drops once a week for all patients. The patients were divided into three groups of similar size according to their total body fat (TBF) percentages: TBF $<25 \%(\mathrm{~N}=10), 25 \%<\mathrm{TBF}<38 \%(\mathrm{~N}=11)$ and $\mathrm{TBF}>38 \%(\mathrm{~N}=10)$. Biochemical tests, 25(OH)D, PTH, OC, and CTX-s were first measured before the beginning of cholecalciferol supplementation. Two further blood samples were obtained within 6 and 12 weeks of the beginning of the study. PTH, 25(OH)D and ionic calcium were measured during the sixth week. In addition to these tests, OC and CTX-s were also measured at the end of the study.

\section{Statistical analysis}

To quantify the differences between the treated and untreated groups regarding the variables measured as a function of time, we used analysis of variance (ANOVA) with repeated measurements. In this model, two factors were taken into account: groups (treated and untreated) and time (0, 6, and 12 weeks). The correlations between variables were determined by Pearson's linear correlation coefficient. To evaluate the influence of baseline values of $25(\mathrm{OH}) \mathrm{D}$ on its elevation after treatment, we divided the treated patients into two groups: $25(\mathrm{OH}) \mathrm{D}$ lower than $20 \mathrm{ng} / \mathrm{mL}$ (insufficiency) and 25(OH)D higher than $20 \mathrm{ng} / \mathrm{mL}$. The two groups were then compared using the Student $t$-test. Statistical analysis was carried out using the SPSS and proc MIXED software of SAS. A $P$ value lower than 0.05 was taken to indicate a statistically significant difference. 


\section{Results}

The mean age of the patients studied was 77.5 years, ranging from 65 to 92 years old. Patients ranged from lean to grade 2 obesity. Body mass index (BMI) ranged from 15.62 to $36.68 \mathrm{~kg} / \mathrm{m}^{2}$ (data not shown). The untreated group had significantly lower $(\mathrm{P}<$ 0.05) PTH levels than the treated groups because they were selected for low levels of PTH. There was also no difference among groups regarding bone remodeling markers (CTX-s and OC; Table 1).

Seventeen 17/42 (40.4\%) patients had insufficient levels of vitamin $\mathrm{D},<20 \mathrm{ng} / \mathrm{mL}$, prior to the beginning of cholecalciferol supplementation. No patient had levels compatible with deficiency, $<5 \mathrm{ng} / \mathrm{mL}$. Only one female $1 / 42(2.38 \%)$ patient presented sufficient levels, $>40 \mathrm{ng} / \mathrm{mL}$, on the occasion of the first blood collection. At the end of the study, 4 treated patients (12.9\%) still had vitamin D levels lower than $20 \mathrm{ng} / \mathrm{mL}$ and only $2 / 42(4.7 \%)$ patients had levels of 40 $\mathrm{ng} / \mathrm{mL}$ or more (Figure 1). No patient had any kind of adverse effects or showed intolerance to the medication. Hypercalcemia was not observed in any patient during this study, but most patients reached only the hypovita- minosis levels (20-40 ng/mL) (15).

The non-treated group had a $2.7 \mathrm{ng} / \mathrm{mL}$ non-significant decrease of the serum levels of $25(\mathrm{OH}) \mathrm{D}$ at the end of 12 weeks. Serum $25(\mathrm{OH}) \mathrm{D}$ levels similarly and significantly increased in the groups that received vitamin D supplementation. The mean elevation was of $6.2 \mathrm{ng} / \mathrm{mL}$ in the group with body fat percentage lower than $25 \%$ and of $8.1 \mathrm{ng} /$ $\mathrm{mL}$ in the groups with body fat percentage between 25 and $38 \%$ and higher than 38\%; hence, no influence of body fat percentage on the increase of serum $25(\mathrm{OH}) \mathrm{D}$ was found (Table 1). After 6 weeks of treatment, serum levels of $25(\mathrm{OH}) \mathrm{D}$ reached a plateau, with the 12-week levels almost identical to those observed at 6 weeks. The elevation of $25(\mathrm{OH}) \mathrm{D}$ levels was not associated with changes in CTX-s or OC (Table 1). We observed no gender differences regarding basal, 6- or 12-week serum 25(OH)D levels. PTH levels did not vary significantly in either group during the 12 -week period of study. Nine patients distributed among all the TBF groups (21.42\%) had PTH levels higher than reference values and normal calcium levels, indicative of a diagnosis of secondary hyperparathyroidism. These patients also had the highest values of bone

Table 1. Basal and 12-week levels of 25(OH)D, PTH, CTX-s, OC, and total calcium in the untreated group and in the groups treated with cholecalciferol, $7000 \mathrm{lU} /$ week, and divided into groups according to body fat percentage.

\begin{tabular}{|c|c|c|c|c|c|c|c|c|}
\hline & \multicolumn{2}{|c|}{ Untreated group } & \multicolumn{2}{|c|}{ TBF $<25 \%$} & \multicolumn{2}{|c|}{$25 \%<\mathrm{TBF}<38 \%$} & \multicolumn{2}{|c|}{ TBF > 38\% } \\
\hline & \multicolumn{2}{|c|}{$\begin{array}{c}\text { Median age }=76 \text { years } \\
\text { Male/female }=4 / 7(N=11)\end{array}$} & \multicolumn{2}{|c|}{$\begin{array}{c}\text { Median age }=76 \text { years } \\
\text { Male/female }=3 / 7(N=10)\end{array}$} & \multicolumn{2}{|c|}{$\begin{array}{c}\text { Median age }=73 \text { years } \\
\text { Male/female }=4 / 7 \quad(N=11)\end{array}$} & \multicolumn{2}{|c|}{$\begin{array}{c}\text { Median age }=77 \text { years } \\
\text { Male/female }=4 / 6(N=10)\end{array}$} \\
\hline & Basal & 12 weeks & Basal & 12 weeks & Basal & 12 weeks & Basal & 12 weeks \\
\hline $25(\mathrm{OH}) \mathrm{D}(\mathrm{ng} / \mathrm{mL})$ & $24.5 \pm 7.1$ & $21.8 \pm 9.2$ & $18.8 \pm 6.4$ & $25.0 \pm 6.0^{a}$ & $22.4 \pm 10.7$ & $30.5 \pm 6.5^{a}$ & $24.2 \pm 7.4$ & $32.3 \pm 7.0^{\mathrm{a}}$ \\
\hline PTH $(p g / m L)$ & $29.6 \pm 8.2^{b}$ & $36 \pm 12.2$ & $58.6 \pm 17.5$ & $57.2 \pm 30.5$ & $51.2 \pm 28.1$ & $52.8 \pm 25.4$ & $53.6 \pm 28.6$ & $50.1 \pm 25.1$ \\
\hline CTX-s (ng/mL) & $0.53 \pm 0.2$ & $0.51 \pm 0.12$ & $0.54 \pm 0.23$ & $0.73 \pm 0.31$ & $0.79 \pm 0.57$ & $0.67 \pm 0.48$ & $0.65 \pm 0.34$ & $0.52 \pm 0.33$ \\
\hline $\mathrm{OC}(\mathrm{ng} / \mathrm{mL})$ & $25.6 \pm 8.6$ & $27.1 \pm 8.1$ & $26.2 \pm 8.1$ & $35.1 \pm 18.1$ & $40.2 \pm 22.8$ & $40.9 \pm 20.8$ & $34.5 \pm 14.2$ & $33.9 \pm 16.6$ \\
\hline $\mathrm{Ca} \mathrm{T}(\mathrm{mg} / \mathrm{dL})$ & $8.8 \pm 0.3$ & $8.9 \pm 0.2$ & $8.8 \pm 0.3$ & $8.8 \pm 0.2$ & $8.8 \pm 0.4$ & $8.8 \pm 0.3$ & $8.84 \pm 0.4$ & $8.8 \pm 0.3$ \\
\hline
\end{tabular}

Data are reported as mean \pm SD. The untreated group was selected for low PTH levels. TBF $=$ total body fat; $25(\mathrm{OH}) \mathrm{D}=25$-hydroxyvitamin $\mathrm{D} ; \mathrm{PTH}$ = parathormone; CTX-s = carboxyl-terminal fraction of type 1 collagen; OC = osteocalcin; $\mathrm{Ca} T=$ total calcium.

aP $<0.05$ for 12 -week values compared to basal values; ${ }^{\text {b }}<0.05$ for basal PTH levels of the untreated group compared to the other groups (ANOVA). 
remodeling markers (OC and CTX-s; P < $0.05)$, but not the lowest $25(\mathrm{OH}) \mathrm{D}$ levels, and at the end of 12 weeks their mean PTH levels decreased from 86.46 to $70.81 \mathrm{pg} / \mathrm{mL}$ $(\mathrm{P}<0.05)$ but with no significant decrease in the levels of bone remodeling markers (data not shown).

Mean elevation in 25(OH)D levels among the patients who received cholecalciferol and presented baseline levels lower than 20 $\mathrm{ng} / \mathrm{mL}$ was 10.15 versus $5.18 \mathrm{ng} / \mathrm{mL}$ for the patients presenting baseline levels higher than $20 \mathrm{ng} / \mathrm{mL}(\mathrm{P}<0.05$; Figure 2$)$.

\section{Discussion}

This was a short-term study designed to evaluate the need to tailor vitamin D doses to body fat, BMI and weight for patients who are over 65 years old. Some studies demonstrated that obese people have lower serum levels of vitamin D when compared to nonobese people (6-11), but few data are available in the literature regarding the influence of weight or percent body fat on the elevation of serum $25(\mathrm{OH}) \mathrm{D}$ levels after vitamin D supplementation (11). With this in mind, we decided to study a population of institutionalized geriatric patients without extreme weights.

Baseline levels of vitamin D are mainly influenced by the seasons of the year, race, age, and vitamin intake (16-18). The role of obesity has been recently evaluated. Compston et al. (9) conducted the first studies comparing the baseline levels of vitamin D between obese and non-obese people and observed that the levels were significantly lower in obese individuals. In their study, the obese population consisted of patients with morbid obesity.

Parikh et al. (19) studied adults of both genders of various races and observed that the obese group $(\mathrm{N}=154$; mean BMI $37.4 \pm$ $6 \mathrm{~kg} / \mathrm{m}^{2}$ ) displayed mean levels of plasma $25(\mathrm{OH}) \mathrm{D}$ of $23.5 \pm 12.2 \mathrm{ng} / \mathrm{mL}$, significantly lower than those observed in the non- obese group $(\mathrm{N}=148$, mean levels of $25(\mathrm{OH}) \mathrm{D}$ of $31 \pm 14.4 \mathrm{ng} / \mathrm{mL})$. Arunabh et al. (20) evaluated a group of 410 healthy women aged 20 to 80 years with BMI ranging from 17 to $30 \mathrm{~kg} / \mathrm{m}^{2}$ and, after adjustments for race, age, season of the year, and vitamin intake, found a discrete but significant correlation $(\mathrm{r}=-0.13, \mathrm{P}=0.013$, multiple regression model) between serum levels of $25(\mathrm{OH}) \mathrm{D}$ and body fat percentage. However, this significance was detected only when distributing the study group into quartiles and by comparing the highest body fat percentage quartile (fat $>42 \%$ ) with the lowest one (fat $<31 \%$ ), with the average serum levels of $25(\mathrm{OH}) \mathrm{D}$ obtained being 17.68 and $22.64 \mathrm{ng} / \mathrm{mL}$, respectively.

Scragg et al. (21) evaluated a group of 390 New Zealand inhabitants consisting of natives and of people of European descent and, similar to our findings, they did not detect any relation between serum levels of 25(OH)D and BMI. In our study there were no differences in baseline serum levels of
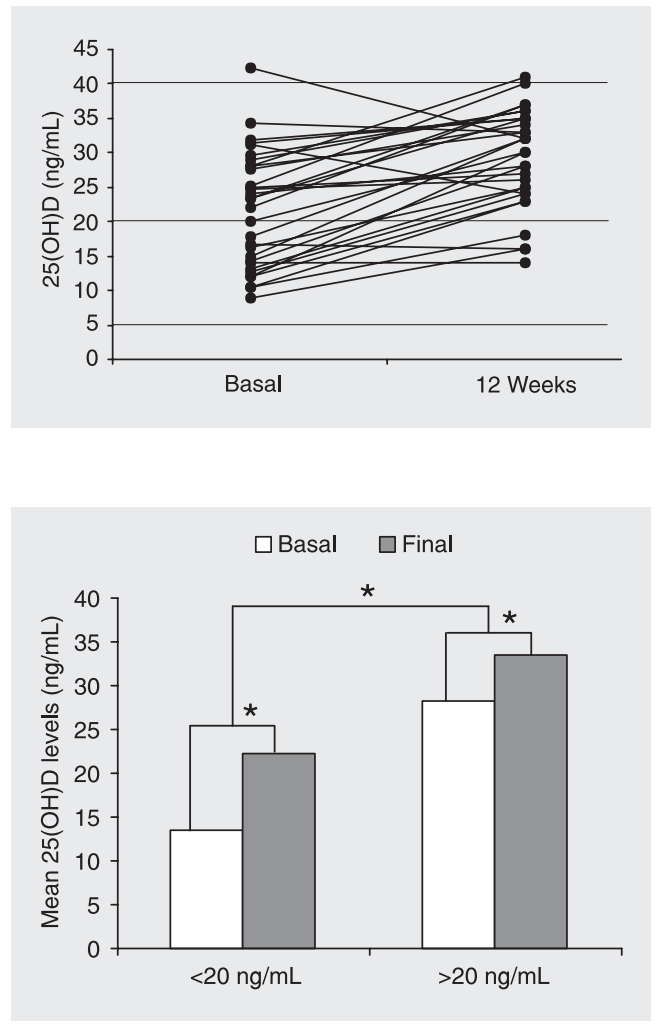

Figure 1. Effect of cholecalciferol on plasma 25(OH)D (ng/ $\mathrm{mL}$ ) at the beginning of the study and after 12 weeks. The subjects received $7000 \mathrm{IU} /$ week of cholecalciferol. 25(OH)D $=25$ hydroxyvitamin $\mathrm{D}$.

Figure 2. Variation of $25(\mathrm{OH}) \mathrm{D}$ levels among the groups of patients that received cholecalciferol for 12 weeks according to their initial levels of plasma 25(OH)D: lower than $20 \mathrm{ng} / \mathrm{ml}$ $(\mathrm{N}=15$, left) and higher than 20 $\mathrm{ng} / \mathrm{mL}(\mathrm{N}=16$, right). Basal values are given in the open columns and final values are given in the filled columns. $25(\mathrm{OH}) \mathrm{D}=$ 25-hydroxyvitamin $\mathrm{D}$. ${ }^{*} \mathrm{P}<0.05$ for the comparisons shown (Student $t$-test). 
$25(\mathrm{OH}) \mathrm{D}$ among the groups when they were divided according to body fat percentage $(<25 \%, 25-38 \%$, and $>38 \%)$. It is important to consider that we studied a geriatric population and none of our patients had extreme weight values.

Vitamin D supplementation is recommended to aged patients presenting loss of bone mass, regardless of its severity (22). Along with calcium intake, it represents the basic treatment of osteoporosis. Chapuy et al. (23) were able to demonstrate a reduction in the risk of femoral neck fractures in aged patients receiving only calcium and vitamin D. Still, one question remains unanswered: what is the ideal dose of vitamin D to be recommended so that sufficient serum levels of $25(\mathrm{OH}) \mathrm{D}$ can be reached? In the last few years, the recommended dose for people aged over 70 years has varied from 600 to 2,000 IU of cholecalciferol a day, well below the toxic doses (24). Lips et al. (25), in a multicenter study, observed that supplementation of 400 to $600 \mathrm{IU}$ cholecalciferol a day promoted a mean elevation of vitamin $\mathrm{D}$ levels of $8.6 \mathrm{ng} / \mathrm{mL}$. Barger-Lux et al. (17) administered cholecalciferol, 1,000 IU a day, for 8 weeks to a group of healthy young men $(\mathrm{N}=116)$, and at the end of this period verified a mean elevation of $11.44 \mathrm{ng} / \mathrm{mL}$ in serum levels of $25(\mathrm{OH}) \mathrm{D}$. Our geriatric patients received 7,000 IU of cholecalciferol a week for 12 weeks and presented a mean increase in 25(OH)D levels of $7.60 \pm 6.8 \mathrm{ng} /$ $\mathrm{mL}$, quite evident after only 6 weeks of supplementation. These levels remained stable between 6 and 12 weeks, allowing us to assume that the elevation peak was reached within 6 weeks or less of supplementation. This dose was only enough to shift most of our patients from insufficiency to hypovitaminosis.

More recently, there have been some issues regarding which factors influence the elevation of serum levels of 25(OH)D after vitamin D supplementation. As the chemical process of hepatic hydroxylation is satu- rable, it is expected that the individuals showing lower starting levels of $25(\mathrm{OH}) \mathrm{D}$ will present a greater increase in serum levels of vitamin D (17). In our study, patients presenting basal levels of $25(\mathrm{OH}) \mathrm{D}$ lower than $20 \mathrm{ng} / \mathrm{mL}$ (mean levels of $13.31 \pm 3.1 \mathrm{ng} /$ $\mathrm{mL}$ ), compatible with vitamin D insufficiency, reached mean values of $22.7 \pm 4.9$ $\mathrm{ng} / \mathrm{mL}$ by the end of the study. This difference was significantly higher than that observed in patients with basal levels of $25(\mathrm{OH}) \mathrm{D}$ higher than $20 \mathrm{ng} / \mathrm{mL}$, whose vitamin D levels varied from $28.22 \pm 5.0 \mathrm{ng} / \mathrm{mL}$ at the beginning of the study to $33.47 \pm 6.1$ $\mathrm{ng} / \mathrm{mL}$ after 12 weeks of vitamin D supplementation. Francis et al. (26), studying a group of 65- to 80-year-old individuals in England receiving 1,000 IU of cholecalciferol a day, observed a baseline serum level of $25(\mathrm{OH}) \mathrm{D}$ of $14.4 \mathrm{ng} / \mathrm{mL}$ that rose to 24.4 $\mathrm{ng} / \mathrm{mL}$ at the end of 6 months of treatment. In turn, Sorva et al. (27), after providing elderly people with cholecalciferol, 1,000 IU a day, reported an elevation of $25(\mathrm{OH}) \mathrm{D}$ from 4.8 to $22.8 \mathrm{ng} / \mathrm{mL}$ at the end of 9 months.

In addition to the starting level of $25(\mathrm{OH}) \mathrm{D}$, weight or body fat percentage has been implicated by some investigators as a determinant of the variation in vitamin $\mathrm{D}$ levels after supplementation. Barger-Lux et al. (17) reported that, after giving cholecalciferol, 800 IU a day, for 8 weeks to a group of young adults, there was an elevation of about $5.6 \mathrm{ng} / \mathrm{mL}$ for those weighing around $55 \mathrm{~kg}$, and of $3.6 \mathrm{ng} / \mathrm{mL}$ for those weighing around $85 \mathrm{~kg}$. We divided the participants in our study into three groups: those with body fat percentage lower than $25 \%$, between 25 and $38 \%$, and higher than $38 \%$, and observed a mean rise in serum levels of $25(\mathrm{OH}) \mathrm{D}$ of $6.2 \pm 6.9 \mathrm{ng} / \mathrm{mL}$ for the first group and of $8.1 \pm 8.5$ and $8.1 \pm 5.3 \mathrm{ng} / \mathrm{mL}$, respectively, for the other two groups, meaning that no relationship between elevation of serum levels of $25(\mathrm{OH}) \mathrm{D}$ and fat percentage was observed. 
The same studies that observed a negative correlation between vitamin $\mathrm{D}$ and adipose tissue also demonstrated higher levels of PTH in obese individuals (6-11). In our study, we did not observe any correlation between $25(\mathrm{OH}) \mathrm{D}$ and body fat tissue or between PTH and adiposity.

We did not find any correlation between elevation of serum levels of $25(\mathrm{OH}) \mathrm{D}$ and body fat percentage, weight or BMI in this group of institutionalized patients. The groups with different body fat percentages had very similar elevations in the levels of $25(\mathrm{OH}) \mathrm{D}$ after vitamin D supplementation. When these patients were provided with cholecalciferol, they at most progressed to hypovitaminosis, meaning that cholecalcif- erol, 7,000 IU a week, was unable to actually improve this condition. Considering that higher doses of cholecalciferol could still be safely supplemented, it should be interesting to provide these patients with a higher dose, able to take them to vitamin D sufficiency and to evaluate the correlation between this dose and body fat percentage. The peak of serum elevation of $25(\mathrm{OH}) \mathrm{D}$ was seen within 6 weeks, and this short interval may be enough to evaluate the increased vitamin D levels after supplementation with oral vitamin D is started. Population-based studies may be indicated to determine if there is a correlation between the increase in serum 25(OH)D levels after oral cholecalciferol supplementation and body fat percentage.

\section{References}

1. Riggs L \& Melton III LJ (1986). Medical progress: Involutional osteoporosis. New England Journal of Medicine, 314: 1676-1686.

2. Kessenich CR \& Rosen CJ (1996). The Pathophysiology of Osteoporosis. In: Rosen CJ (Editor), Osteoporosis - Diagnosis and Therapeutic Principles. Humana Press Inc., Clifton, NJ, USA, 47-63.

3. Need AG, Horowitz M, Morrise HA et al. (2000). Vitamin D status: Effects on parathyroid hormone and 1,25-dihydroxyvitamin $D$ in postmenopausal women. American Journal of Clinical Nutrition, 71: 1577-1581.

4. Harris SS, Soteriades E, Coolidge JA et al. (2000). Vitamin D insufficiency and hyperparathyroidism in a low income, multiracial, elderly population. Journal of Clinical Endocrinology and Metabolism, 85: 4125-4130.

5. Corless D, Beer M, Boucher BJ et al. (1975). Vitamin D status in long-stay geriatric patients. Lancet, 1: 1404-1406.

6. Bell NH, Epstein S, Greene A et al. (1985). Evidence for alteration of the vitamin D-endocrine system in obese subjects. Journal of Clinical Investigation, 76: 370-373.

7. Liel Y, Ulmer E, Shary J et al. (1988). Low circulating vitamin D in obesity. Calcified Tissue International, 43: 199-201.

8. Bell NH, Shaw S \& Turner RT (1984). Evidence that 1,25-dihydroxyvitamin D3 inhibits the hepatic production of 25-hydroxyvitamin D in man. Journal of Clinical Investigation, 74: 1540-1544.

9. Compston JE, Vedi S, Ledger JE et al. (1981). Vitamin D status and bone histomorphometry in gross obesity. American Journal of Clinical Nutrition, 34: 2359-2363.

10. Mawer EB, Backhouse J, Holman CA et al. (1972). The distribution and storage of vitamin $D$ and its metabolites in human tissues. Clinical Science, 43: 414-431.

11. Worstman J, Matsuoka LY, Chen TC et al. (2000). Decreased bioavailability of vitamin D in obesity. American Journal of Clinical Nutrition, 72: 690-693.

12. Bischoff-Ferrari HA, Dietrich T, Orav EJ et al. (2004). Positive asso- ciation between 25-hydroxy vitamin $\mathrm{D}$ levels and bone mineral density: a population-based study of younger and older adults. American Journal of Medicine, 116: 634-639.

13. Chapuy MC, Arlot ME, Delmas PD et al. (1994). Effect of calcium and cholecalciferol treatment for three years on hip fractures in elderly women. British Medical Journal, 308: 1081-1082.

14. Lips P, Graafmans WC, Ooms ME et al. (1994). The effect of vitamin $D$ supplementation on the incidence of hip fractures in elderly people. Journal of Bone and Mineral Research, 9 (Suppl 1): 112 (Abstract).

15. Zittermann A (2003). Vitamin D in preventive medicine: are we ignoring the evidence? British Journal of Nutrition, 89: 552-572.

16. Kartz BS, Jackson GJ, Hollis BW et al. (1993). Diagnostic criterion of vitamin D deficiency. Endocrinologist, 3: 248-253.

17. Barger-Lux MJ, Heaney RP, Dowell S et al. (1998). Vitamin D and its major metabolites: serum levels after graded oral dosing in healthy men. Osteoporosis International, 8: 222-230.

18. Jacques PF, Felson DT, Tucker KL et al. (1997). Plasma 25hydroxyvitamin $\mathrm{D}$ and its determinants in an elderly population sample. American Journal of Clinical Nutrition, 66: 929-936.

19. Parikh JS, Edelman M, Uwaifo Gl et al. (2004). The relationship between obesity and serum 1,25 dihydroxy vitamin $D$ concentrations in healthy adults. Journal of Clinical Endocrinology and Metabolism, 89: 1196-1199.

20. Arunabh S, Pollack S, Yeh J et al. (2003). Body fat content and 25hydroxyvitamin D levels in healthy women. Journal of Clinical Endocrinology and Metabolism, 88: 157-161.

21. Scragg R, Holdaway I, Singh V et al. (1995). Serum 25 hydroxyvitamin D3 is related to physical activity and ethnicity but not to obesity in a multicultural workforce. Australian and New Zealand Medical Journal, 25: 218-223.

22. Ooms ME, Ross JC, Bezemer PD et al. (1995). Prevention of bone loss by vitamin $\mathrm{D}$ supplementation in elderly women: a randomized double-blind trial. Journal of Clinical Endocrinology and Metabolism, 
80: 1052-1058.

23. Chapuy MC, Arlot ME \& Duboeuf F (1992). Vitamin D3 and calcium to prevent hip fractures in elderly women. New England Journal of Medicine, 327: 1637-1642.

24. Vieth R (1999). Vitamin D supplementation, 25-hydroxyvitamin D concentrations, and safety. American Journal of Clinical Nutrition, 69: 842-856.

25. Lips P, Graafmans WC, Ooms ME et al. (1996). Vitamin D supplementation and fracture incidence in elderly persons. A randomized, placebo-controlled clinical trial. Annals of Internal Medicine, 124:
400-406.

26. Francis RM, Boyle IT, Moniz C et al. (1996). A comparison of the effects of alphacalcidiol treatment and vitamin D2 supplementation on calcium absorption in elderly women with vertebral fractures. Osteoporosis International, 6: 284-290.

27. Sorva A, Risteli J, Risteli L et al. (1991). Effect of vitamin D and calcium on markers of bone metabolism in geriatric patient with low serum 25-hydroxyvitamin D levels. Calcified Tissue International, 49 (Suppl): S88-S89. 